\title{
Capital Gains Tax on Investment, Infrastructural Facilities Provision and Gross Domestic Products in Nigeria
}

\author{
Osho, Augustine E Ph.D \\ Bursary Department, Ekiti State University, P. M. B. 5363, Ado-Ekiti, Nigeria \\ Adeseyoju, Adeyemi A \\ Audit Department, Ondo State University of Scirnce and Technology, P. M. B. 353, Okitipupa, Ondo Sate, \\ Nigeria \\ Idowu, Abiodun S \\ Internal Audit Department, Federal College of Agric, P. M. B. 724, Akure, Ondo State, Nigeria
}

\begin{abstract}
This paper examined the influence of Capital Gains Tax (CGT) on Investment (INV), Infrastructural Facilities Provision (IFP) and Gross Domestic Products (GDP) in Nigeria. Ex-post facto research design was adopted with data obtained from Central Bank of Nigeria (CBN) Statistical Bulletin and Federal Inland Revenue Service (FIRS) tax reports, 2017. The data collected were presented in descriptive statistics and correlation analysis performed. Augmented Dickey Fuller (ADF) Unit Root test was used to ascertain the stationarity of variables, and the Johenson Co-integration trace and Eigenvalue test was used to show the long-run relationship of variables. The test of hypotheses using OLS regression models revealed that Capital Gains Tax is positively and significantly related to investment and infrastructural facilities in Nigeria. It is recommended that government should ensure that capital gains tax is properly administered, efficiently managed and accounted for, to enable the citizenry reap the benefits it confers on investments, Infrastructural facilities provision and gross domestic products in Nigeria.

Keywords: Capital Gains Tax, Gross Domestic Products, Infrastructural Facilities Provision, Investment

DOI: $10.7176 / J R D M / 57-06$
\end{abstract}

Publication date:July $31^{\text {st }} 2019$

\subsection{Introduction}

Those who shape state and local fiscal policy have had a sustained interest in the role that taxation plays in the economic development of states, regions, cities, and special districts or zones. At least 75 studies of employment growth, investment growth, or firm location include an analysis of taxes. Interest in the topic is fuelled further when firms complain about the business climate in general or about taxation. The political, economic and social development of any country depends on the amount of revenue generated for the provision of infrastructure in that given country. However, one means of generating the amount of revenue for providing the needed infrastructure is through a well structure tax system. Azubike (2009) opines that tax is a major player in every society of the world. The tax system is an opportunity for government to collect additional revenue needed in discharging its pressing obligations. A tax system offers itself as one of the most effective means of mobilizing a nation's internal resources, which creates an environment conducive to the promotion of economic growth.

In recent times, revenue mobilization in developing countries has become imperative. Revenue mobilization and generation is a major requirement needed by countries for the actualization of sufficient finance. Taxation has become a vital source of revenue to the government because of its consistency, and particularly, the capital gains tax. Capital Gains Tax (CGT) refers to the tax chargeable on the gains that accrue to an individual or a company on the transfer of property such as marketable securities, buildings and lands situated in Nigeria (FIRS, 2014).

Taxation of property transfer has become an issue of great concern in Nigeria since it has significant fiscal and economic implication to the government. Most government problems are associated with the budget deficit since cash flows have a narrow tax base. There are also massive reliefs and exemptions from taxation that reduce its cash flow contribution. Continued budget deficit has attracted excessive attention and studies from international and local persons, calling for better administration of the CGT. CGT is significant since it has great effect on the economy. Through the CGT, the government can expand its tax base which can then increase its amount of revenue from taxes for improving the economy. It also influences investment in the property since the profit accrued from the exchange of properties becomes chargeable profit and liable to tax.

Nevertheless, Nigeria and other African Countries are today facing series of challenges when it comes to optimizing taxation revenue for economic and social growth while aiming to reach development targets. The most glaring difficult challenge is how to find the optimal balance between a tax regime that is business and investment friendly while at the same time leveraging enough revenue for public service delivery which in turn makes the 
economy more attractive to investors. The CGT taxation system in Nigeria has not being fully tapped and maximized and its role in promoting economic and social activities and growth is not felt because of its poor administration.

Therefore, identifying the impact of capital gains taxation on the Nigerian economic becomes imperative this time, as there is an urgent need to examine more deeply and to look into the implications of capital gains tax (which has not received much attention in the literature), on investment, infrastructural facilities provision in Nigeria. This study will not only guarantee improved revenue base for the country but also position the country properly to take full advantage offered by the new millennium global tax reform system.

\subsection{Literature Review \\ 2.1.1 Concept of Taxation}

All over the world, taxation as a major instrument for revenue generation remains one of the main sources of revenue to governments. Taxation is very important to Nigerian Government in its annual budget preparation. Tax system is a forum for government to collect additional revenue needed to discharge its pressing obligations like building schools and hospitals, construction and maintenance of roads for its citizens (Ezemma, 2013). According to Abata (2014), the tax system is one of the most powerful sources of revenue available to any government to stimulate and develop its economy. Edame and Okoi, (2014) in their work stated that 'A tax system offers itself as one of the most effective means of mobilizing a nation's internal resources and it lends itself to creating an environment conducive to the promotion of economic growth'.

When taxes are used as a proxy for fiscal policy, Engen and Skinner (1999) as cited in Tosun and Sohrab (2005) defines different areas by which taxes affect economic growth and investment in a country. First, taxes can serve as constraint to investment rate through such taxes as corporate and personal income, capital gain taxes. Second, taxes can slow down growth in labour supply by disposing labour leisure choice in favour of leisure. Third, tax policy can effect on research and development expenditure. Fourth, taxes can lead to a flow of resources to other sectors that may have lower productivity. Finally, they opined that high taxes on labour supply can distort the efficient use of human capital if saddled with high tax burdens even though they have high social productivity. These views are summed up in Musgrave and Musgrave (2004) who quipped that economic effects of tax include micro effects on the distribution of income and efficiency of resources used as well as macro effect on the level of capacity output, employment, prices and growth.

\subsubsection{Capital Gains Tax (CGT)}

Capital gains tax is a tax levied on capital gains or profits from the sale of specific types of assets. It is a tax calculated on profits resulting from the higher sales price over the original purchase price at the disposal of assets. According to Osho, Ajibola and Omolola (2018), CGT refers to the tax imposed on capital gains, which is the profit realized on the sale of a non-inventory assets. The most common capital gains are realized from the sale of stocks, bonds, precious metals, and property. Capital gains taxes arise only when assets are realized and not while being held by the investors as one can own stocks or bonds that appreciate every year, capital gains tax cannot be charged on the shares until sold. Capital gains are earned on types of assets such as stocks, bonds, precious metals or real estate property, plant and equipment (PPE), and so on.

Embuka (2014) pointed out that capital gains tax is levied on individuals and corporate bodies when gains arise from the disposal of capital assets. Aguolu (2014) stated that capital gains tax is chargeable in respect of options, any form of property created by a person disposing of it, stocks and shares of all descriptions. There are relevant Tax Authorities responsible to assess and collect the tax.

Most countries' tax laws provide for some form of capital gains taxes, these laws vary from country to country and even, some countries do not apply a capital gains tax at all. In Canada, for example, residents pay half of their marginal tax rate on capital gains. In the United States, individuals and corporations are subject to capital gains taxes each year on their annual net capital gains.

Although they are both seen as profit, capital gains, which result from sales of an asset, are not the same as dividends earned on an asset (investment asset) The Capital Gains Tax rate for short-term capital gains (on assets held under a year) is usually the same as the tax rate on earned income or other types of ordinary income. The same rules apply for long and short-term losses respectively. In the USA, dividends are taxed as ordinary income, for taxpayers in 15 percent and higher tax brackets, while in Nigeria, capital gains taxes charged at a flat rate of 10 percent, applies to anyone who sells an asset for profit, the rate was reduced from 20 percent to 10 percent with effect from 1st January, 1996.

Capital Gains Taxes are taxes on gains or profits arising from disposal of assets. Some of the assets that attract capital gains tax on disposal are plants and machinery, land and buildings, investment assets such as shares, treasury certificates, goodwill and so on. Capital gains tax was first introduced in Nigeria in 1967 through capital gains tax Act No. 44 of 1967 this according to Edotsu (2008), it applied throughout the Federation on companies until was amended through Decree No. 30 of 1999, to include individuals, partnerships and companies. 
The capital gains tax discourages investment and hence, an investor can avoid this tax in many ways; this constitutes challenges for the capital gains taxes in Nigeria, One is the fact that it is difficult to tax property of nonresident person who own assets in another country. Apart from this, according to Marotta (2017), investors can decide to realize losses to offset and cancel their gains for a particular year. Also, improper record or lack of record is another bane of the capital gains tax in the sub-Sahara Africa.

\subsubsection{Capital gains Tax Administration}

Tax Administration means the process of implementing decisions and policies relating to taxation. According to Raymond (1980) as cited in Ezemma (2013) who sees administration as a systematised process of implementing the policies of the government while the capital gains tax on individuals are administered by the State's Board of Internal Revenue (SBIR) the Federal Inland Revenue (FIRS) is responsible for collections of capital gains tax accruing to corporate entities, the residents of Federal Capital Territory and non-residents of the country.

The purpose of the administration of capital gains tax is to ensure that every disposal of taxable capital assets by either individuals or corporate organizations are effectively taxed (Ezemma \& Mohammed, 2017). However, collection of capital gains tax involves some challenges. Adequate record keeping of the property is very essential to both the taxpayer and the tax authorities. To the taxpayer, to avoid being over taxed and to the tax administrators to charge appropriate capital gains tax. Specifically, it identifies current challenges to capital gains tax administration.

A cited by Edame, and Okoi, (2014), Adebayo (2017) opined that lack of data or record keeping in order for the tax authorities to be aware of when a capital gain has been made and liable to pay capital gains tax and reliable and genuine data and typical bureaucratic lethargy to investigate what actually capital gains payable are major problems. In real practice, what is charged by the tax authorities, as capital gains tax, is the entire amount or capital derived by the owner of the asset when disposing off that asset. This, he further explained, contrast with the provision of the Law which requires that only the exact gain, after deduction of allowances, are chargeable to capital gains tax.

Another problem as pointed out by Ipaye (2017) is that of high rate of inflation in the country. This erodes the real value of assets and consequently leaves the assets owners at the losing end in real terms when such assets are disposed-off stating that the rate during the time of inflation is always high and this encourages tax avoidance by many taxpayers. He therefore suggested introduction of allowance for inflation in the computation and payment of capital gains tax in Nigeria as applicable in some countries.

\subsubsection{Net Capital Gains}

Net capital gains refer to the total amount of capital gains minus any capital losses. This means if an investor sells two stocks during the year, one for a profit and an equal one for a loss, the amount of the capital loss on the losing investment counteracts the capital gain from the profitable investment. As a result, the taxpayer has zero net capital gains, meaning he does not incur any Capital Gains Tax.

Investors who have both long and short term gains and losses can easily compute their final net gain. First, it is necessary to add all like-kind gains and losses together. For example, if an investor has four short-term gains, then these amounts must be added together to get a final total of all short-term gains. The same thing must be done with long-term gains and long and short-term losses. Then, when each type of gain and loss has been aggregated into four separate totals, the short-term gains are netted against the short-term losses to produce a net short-term gain or loss. The same thing is done with the long-term gains and losses. Then, these two numbers are netted against each other to produce a final net number that is reported on the return.

Capital gains tax (CGT) is a tax on profits accruing from the disposal of assets. It is charged at a flat rate of 10 per cent. Embuka (2014) pointed out that capital gains tax is levied on individuals and corporate bodies when gains arise from the disposal of capital assets. Aguolu (2014) stated that capital gains tax is chargeable in respect of options, any form of property created by a person disposing of it; stocks and shares of all descriptions. There are relevant Tax Authorities responsible to assess and collect the tax.

\subsubsection{Capital Gains Tax on Personal Assets}

The Capital Gains Tax Act, CAP 354 LFN; 1990 describe chargeable assets as all forms of property whether situated in Nigeria or not; options, debts and incorporeal property generally; any currency other than Nigerian currency; and any form of property created by the person disposing of it, or otherwise coming to be owned without being acquired. An asset or property in respect of which qualifying expenditure had been incurred under the Personal Income Tax Act (PITA), the Companies Income Tax Act (CITA), or the Petroleum Profits Tax Act (PPTA) is not exempted. From the foregoing, it is assumed all forms of assets are subjected to the CTG; however, the stockholders and investors in government securities are favoured in Section 30. The Act goes on to list some exemptions such as stocks and shares, gains accruing from disposal of Nigerian government securities, that is, the 
Nigerian treasury bonds, savings certificates and premium bonds issued under the Savings Bonds and Certificates Act.

Assets outside Nigeria are defined assets situated outside Nigeria whereby an individual in temporary stay Nigeria without intention of establishing residence in the country. As regard corporate bodies, these are companies which are not Nigerian companies in which case their activities are managed and controlled outside Nigeria. In any year of assessment, the law provides that capital gains tax shall be charged on any amounts received or brought into Nigeria in respect of any chargeable gains such amounts being treated as gains accruing when they are received or brought into Nigeria. This provision can act as disincentive to foreigners willing to invest in Nigeria yet; foreign investment plays important roles in economic development of many developing nations. However, it is always very difficult to levy tax on non-resident persons in a country who owns property in another country as cited in Kenyan Academia, 2017.

\subsubsection{Conceptual framework of Capital Gains Tax on Investment, Infrastructural Facilities and Gross Domestic Products in Nigeria}

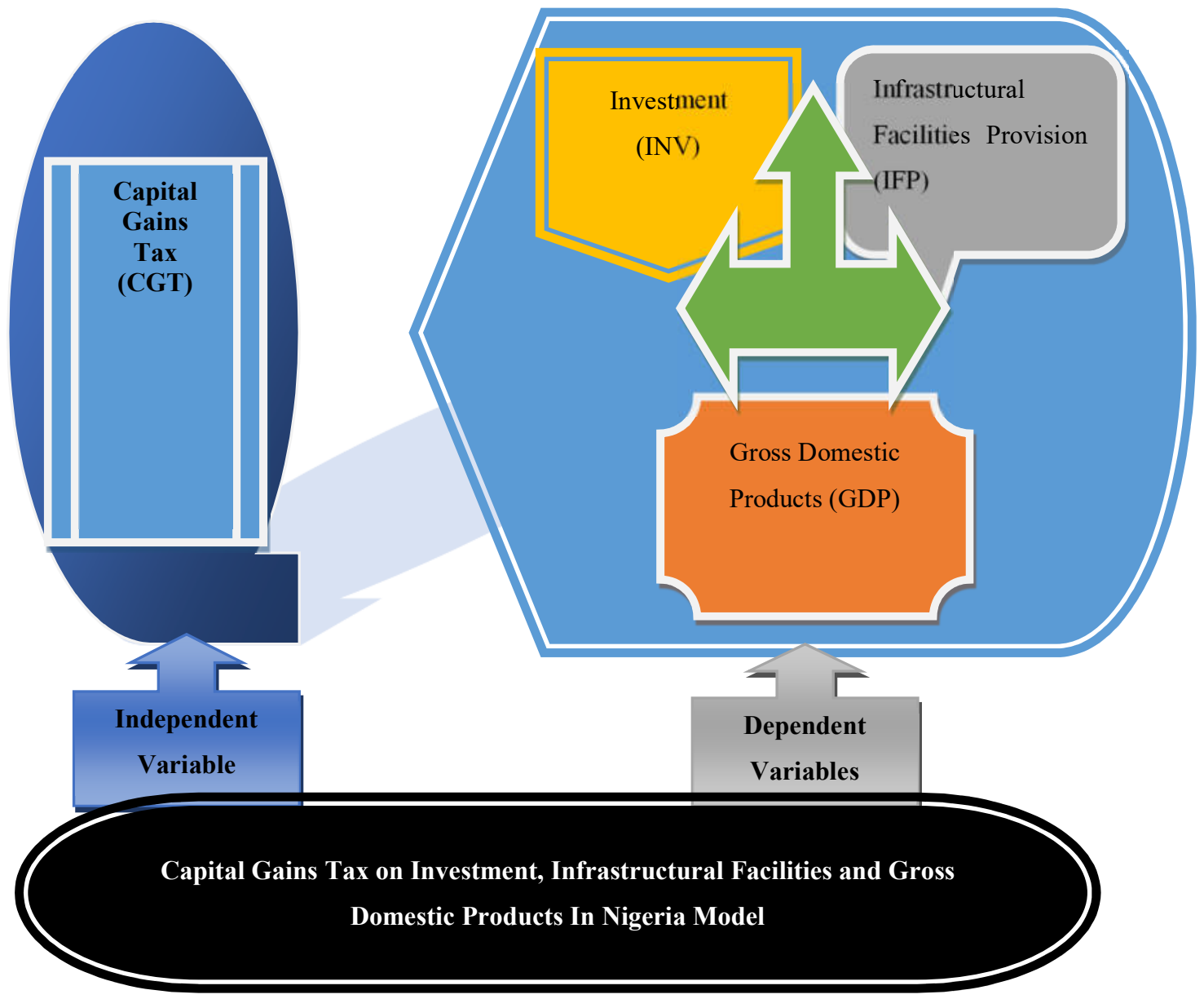

\subsection{Theoretical Framework}

There are many theories in taxation, but for the purpose of this study, the optimal theory of taxation is adopted. There are three main advocates of this theory, Ramsey (1927) advocated linear commodity taxation to raise revenues and redistribute; Pigou (1920) advocated the linear commodity taxation to correct for externalities; and Mirrlees (1971) advocated the nonlinear income taxation. Optimal theory employs a normative approach to tax analysis that is based on the commonly used tools of welfare economics. The theory expects that a tax system should be able to raise taxes in such a way that treats the people fairly, reduces the obstruction and interference in economic decisions and does not inflict undue costs on taxpayers or tax administrators. 
Optimal taxation theory is all about maximizing the social welfare of the individuals in the society. Optimal taxation typically treats the social planner as a utilitarian who has a social welfare function that is based on the utilities of individuals in the society. Inferring from the theory, the government is the social planner and responsible for creating a good tax system for the purpose of revenue generation and also for welfare of the taxpayer. The basic goal is to choose a tax system that maximizes the welfare of the citizens in the society. In simple terms, the social planner (the government) is responsible for providing the various infrastructural facilities with the use of the revenue gotten from tax. Thus, this is the anchor for this study.

\subsection{Empirical Review}

Adefila and Bulus (2014) suggested that there are spatial inequalities in infrastructural development in Plateau State, Nigeria. Methodology adopted was the survey research design, and structured questionnaire distributed to one thousand and twenty $(1,020)$ randomly sampled Nigerian citizens. The study employed standardized score (Zscore) analytical technique. The result revealed substantial inter-local government disparities in overall levels of infrastructural development in the study area and a lopsided spatial pattern of infrastructural development. Basically, infrastructural development was not even across the state and this may be based on the managerial pattern of the local government as to usage of fund.

Nwite (2015) noted that the money generated by government from tax revenue is not evident in the level of development in Nigeria as poverty, unemployment, low standard of living and poor infrastructural facilities still remain at a very high rate. He furthered noted that it is indeed worrisome that the tax reforms to ameliorate the tax/infrastructure deficit gap has not yet recorded significant improvement.

Okoli and Afolayan (2015) in their study opined that Value Added Tax (VAT) contributes substantially to revenue of Nigeria. Error Correction Model (ECM) was used for the analysis of the data gathered for the period 1994 2012. From the study, it was observed that VAT is the second long term source of the total federally collected revenue.

Chibu and Njoku (2015), examined the impact of taxation on the Nigerian economy for the period 1994 -2012. The variables used in the model were subjected to Augmented Dickey Fuller Unit Root test, which revealed that the variables were stationary. The co-integration test also revealed that the variables are co-integrated and that long run relationship existed between the variables. The results of the statistical analysis revealed that positive relationship also existed between the explanatory variables (Custom and Excise Duties, Company Income Tax, and Petroleum Profit Tax) and the dependent Variables (Gross Domestic Product, and Unemployment). The study therefore, recommended total restructuring of the tax system in the country and the provision of basic amenities (good roads, steady power supply, internal security, etc) which will encourage individuals and corporate organizations to honour their tax obligations in Nigeria.

Babalola and Aminu (2011), also looked to the impact of taxation on economic growth in Nigeria over the period 1977- 2009. They examined the Unit roots of the series using the Augmented Dickey - Fuller technique after which the co-integration test was conducted using the Engle - Granger Approach. Error correction models were estimated to take care of short- run dynamics. The overall results indicated that productive expenditure did positively impacted on economic growth during the period of coverage and a long-run relationship exists between them as confirmed by the co-integration test.

\subsection{Methodology}

The ex-post facto design is used in this study because it is not possible to directly manipulate or control any of the independent variables. The researchers used data obtained from Central bank of Nigeria (CBN) Bulletin, 2017, and the Federal Inland Revenue Service (FIRS) Tax Statistics, 2017. Data for capital gains tax (CGT) is obtained from FIRS tax statistics, while data for investment (INV), infrastructural facilities provision (IFP) and gross domestic products (GDP) are obtained from CBN bulletin. The data obtained for the study were analysed with descriptive statistics and correlation using both Pearson Moment Correlation test. Since the data used is time series, the stationarity of the series is tested using the Augmented Dickey Fuller (ADF) Unit Root test. The long-run relationship of the variables is shown in the Johenson Co-integration Trace and Eigenvalue tests.

\subsection{Regression Models Specification}

To test the three Hypotheses formulated in the study, three univariate regression models are specified; thus,

$\mathrm{INV}_{\mathrm{t}}=\beta_{0}+\beta_{1} \mathrm{CGT}_{\mathrm{t}}+\mathrm{e}_{\mathrm{t}}$

$\mathrm{IFP}_{\mathrm{t}}==\beta_{0}+\beta_{1} \mathrm{CGT}_{\mathrm{t}}+\mathrm{e}_{\mathrm{t}}$

$\mathrm{GDP}_{\mathrm{t}}==\beta_{0}+\beta_{1} \mathrm{CGT}_{\mathrm{t}}+\mathrm{e}_{\mathrm{t}}$

Where CGT is Capital gains tax, serving as the independent variable in all three models with INV, IFP and GDP being the dependent variables denoting Investment, Infrastructural Facilities Provision and Gross Domestic Products respectively. 
Apriori Expectations: it is expected that the coefficient on CGT (i.e. $\beta_{1}$ ) in all three models will be positive and statistically different from zero (i.e. with p-values less than 0.05), for the null hypotheses to be rejected. Otherwise, accept Ho.

4.0 Results

Table 1: Descriptive statistics of CGT, INV, IFP and GDP

\begin{tabular}{|l|c|c|c|c|}
\hline & CGT & INV & IFP & GDP \\
\hline Mean & 2968.328 & 3235.491 & 189.8788 & 49563.71 \\
\hline Median & 2518.450 & 2087.256 & 212.9325 & 41721.72 \\
\hline Maximum & 8513.000 & 12060.99 & 315.5864 & 113711.6 \\
\hline Minimum & 433.9000 & 119.2500 & 35.99577 & 6897.482 \\
\hline Std. Dev. & 2180.840 & 3750.484 & 97.66005 & 35088.94 \\
\hline
\end{tabular}

Source: Researchers' Descriptive statistics Computation

Table 1 presented the descriptive statistics for the dependent and independent variables (CGT = Capital Gains Tax, $\mathrm{INV}=$ Investment, IFP $=$ Infrastructural Facilities Provision, GDP $=$ Gross Domestic Products which measures Economic Development). The standard deviation of the variables ranges from 97.66 to 35088. IFP has the lowest standard deviation, followed by CGT, then INV and finally GDP. The relatively high standard deviation for all the study variables may be an indication that the sampled data for the study is not normally distributed.

The table also indicates an average or mean value of 2968 for CGT. The minimum and maximum values of CGT during the study period are 8513 and 433.9 respectively. These values imply that the smallest capital gains tax collected by the Federal Inland Revenue service (FIRS) in the sampled period was 433.9 billion, with the highest CGT collection being 8513 billion naira. This shows that the FIRS on average receive about 2968 billion naira as CGT in Nigeria.

Similarly, the table shows that investment made by the Nigerian government (both direct and portfolio) has a mean value of 3235.5 during the study period, with the maximum and minimum investments made being 12060 billion naira and 119.25 billion naira respectively. Overall, the values indicate that the investment in Nigeria is high.

The table further revealed a mean value of 189.9 for infrastructural facilities provision. The value implies that on average, 189.9 billion naira was expended on infrastructural facilities provision in the period under study. The maximum and minimum values of IFP were 315.59 and 36.0 billion naira respectively.

Finally, the table revealed a mean value of 49563.7 for GDP, with minimum and maximum GDP values being 6897.4 billion naira and 113711.6 billion naira respectively. The values imply that on average, the economic development indicator of the Nigerian economy is large GDP, and increasing steadily.

\subsubsection{Correlation Analyses}

Table 2: Pearson correlation coefficients and p-values (in italics) matrix of variables studied.

\begin{tabular}{|l|c|c|c|c|}
\hline & CGT & INV & IFP & GDP \\
\hline CGT & 1.000000 & & & \\
\hline INV & ----- & & & \\
\hline & 0.876857 & 1.000000 & & \\
\hline IFP & 0.0000 & ---- & & \\
\hline & 0.678572 & 0.499545 & 1.000000 & \\
\hline GDP & 0.0020 & 0.0348 & ----- & \\
\hline & 0.936369 & 0.929350 & 0.672391 & 1.000000 \\
\hline
\end{tabular}

Source: Researchers' Pearson correlation Computation

Table 2 presents correlation values between dependent and independent variables and the correlation among the independent variables themselves. These values are generated from Pearson Correlation output.

CGT is positively correlated with INV (with a coefficient of $0.88, p=0.000$ ). The high positive coefficient between these variables in Nigeria suggests that capital gains tax is associated with improved investments made by the government.

The table also revealed a positive correlation coefficient between CGT and IFP (with a coefficient of 0.68 , $p=0.002$ ). The significant positive coefficient between them is an indication that capital gains tax is significantly correlated with infrastructural facilities provision in Nigeria. 
Similarly, CGT is positively associated with the GDP (with a coefficient of $0.94, p=0.000$ ). The positive relationship between them shows that capital gains tax has a direct relationship with the economic development of Nigeria in the period studied.

Finally, it is observed that the dependent variables of the study are positively and significantly correlated, with INV positively correlating with IFP and GDP by positive significant coefficients of 0.50 and 0.93 respectively, and IFP positively correlating with GDP by a coefficient of 0.67 . Overall, the positive and significant relationships are expected since increase in both investment and infrastructural facilities provision will create an increase in economic development.

\subsubsection{Unit Root Test}

The Augmented Dickey Fuller (ADF) Test is used to first determine the stationarity in the serial data of variables, before proceeding to test for regression co-integration, VAR and Granger Causality. This unit toot testing was applied at level, first difference and second difference to ascertain the order of integration of the time series data. The result is presented below:

Table 3: Summarized Results of Augmented Dickey Fuller (ADF) Test

\begin{tabular}{|l|c|c|c|c|c|c|c|}
\hline Variables & \multicolumn{2}{|c|}{ First Diff } & \multicolumn{2}{c|}{ Second Diff } & $\begin{array}{c}P \text { - } \\
\text { Value }\end{array}$ & $\begin{array}{c}\text { Order of } \\
\text { Integration }\end{array}$ & Conclusion \\
\hline & ADF Test & $\begin{array}{c}\text { Critical } \\
\text { Value } \\
(5 \%\end{array}$ & ADF Test & $\begin{array}{c}\text { Critical } \\
\text { Value } \\
(5 \%\end{array}$ & & & \\
\hline CGT & -4.406977 & -3.119910 & & & 0.0055 & 1 & $1(1)$ \\
\hline INV & -7.215165 & -3.081002 & & & 0.0000 & 1 & $1(1)$ \\
\hline IFP & & & -4.591183 & - & 0.0028 & 1 & $1(2)$ \\
\hline GDP & & & -5.045041 & - & 0.0014 & 1 & $1(2)$ \\
\hline
\end{tabular}

Source: Researchers' Field Survey Computation

The result of the ADF test presented in table 1 above shows that the time series data of CGT and INV was stationary or has no unit root at first difference. The null hypotheses of the unit root property of CGT and INV were rejected at first difference since the Absolute ADF test value $>$ Absolute critical value at 5 per cent. While the time series data of IFP and GDP were stationary a second difference, where the Absolute ADF test values exceeded their Absolute critical values@5 per cent.

\subsubsection{Co-Integration Test}

Here two statistical tests are carried out to test the existence of long-run equilibrium between the series in the regression models. 
Table 4: Johenson Co-Integration Test results

\section{Unrestricted Co-integration Rank Test (Trace)}

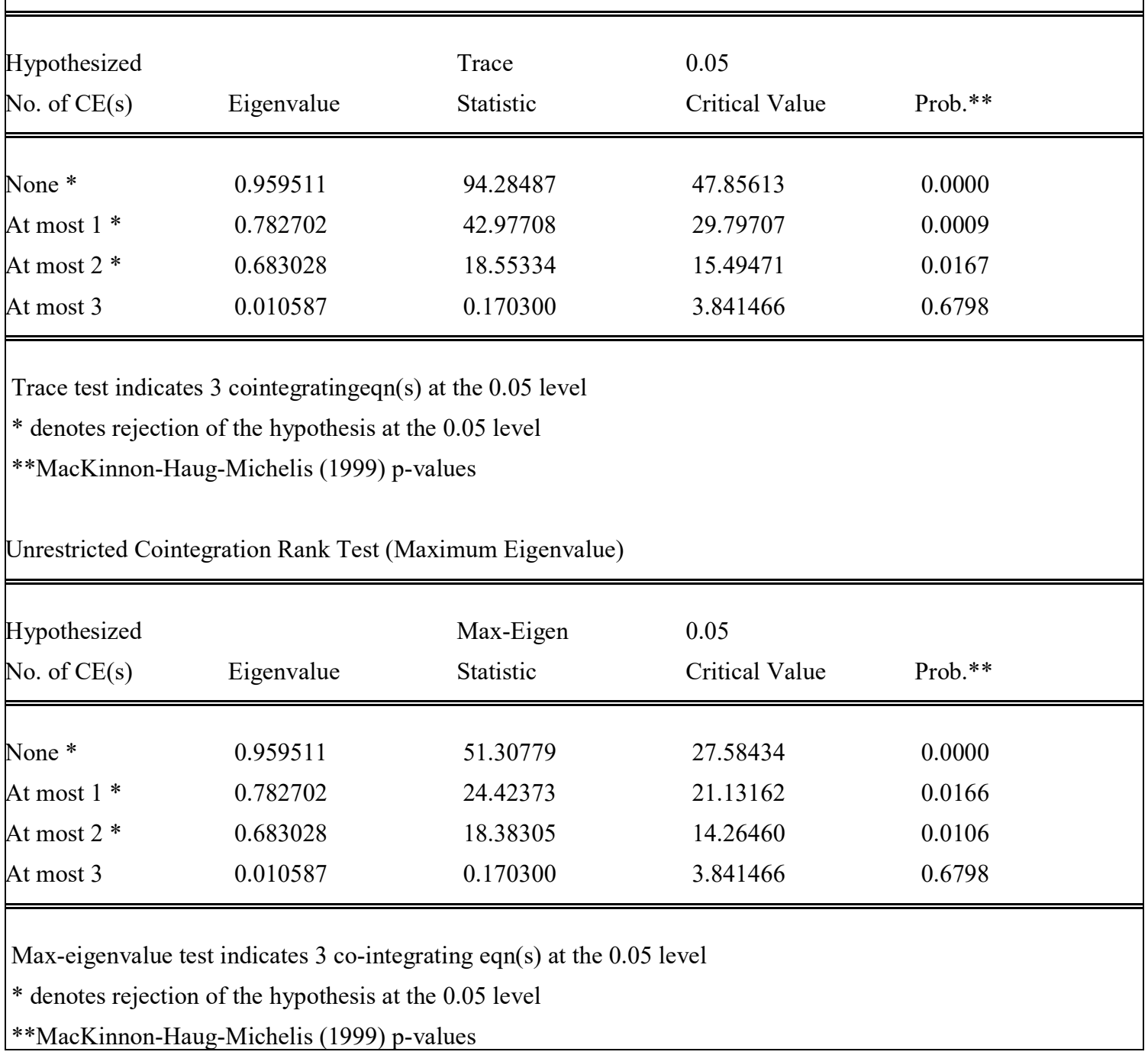

Source: Researchers' Co-Integration Test E-views 9.5

From the tables above, the trace test gave 3 co-integrating equations and the maximum eigenvalue also gave 3 . This means that at the 5 per cent level of significance, there are co-integration vectors in the model, implying a long run relationship between the variables. This shows that there is long run relationship between CGT and all the explained variables. The result indicates that, in the long run; the dependent variables can be efficiently predicted using the specified independent variable. Hence, the regression models specified will be analysed. 


\subsubsection{Regression Result/ Test of Hypotheses}

Table 5: Average Slope, t-statistics and $p$-values from annual time series regressions of capital gains tax (measured as debt ratio) on Investment (INV), Infrastructural Facilities Provision(IFP) and Gross domestic Products (GDP), between 2000 - 2017.

Panel A: OLS Regressions Result for Hypothesis 1

\begin{tabular}{|c|c|c|}
\hline Intercept & CGTR $^{2}$ & \\
\hline Coefficient & 1240.65 & $1.507^{* * *} 0.75$ \\
\hline t-statistics & (7.296) & \\
\hline Prob & & 0.000 \\
\hline
\end{tabular}

Panel B: OLS Regressions Result for Hypothesis 2

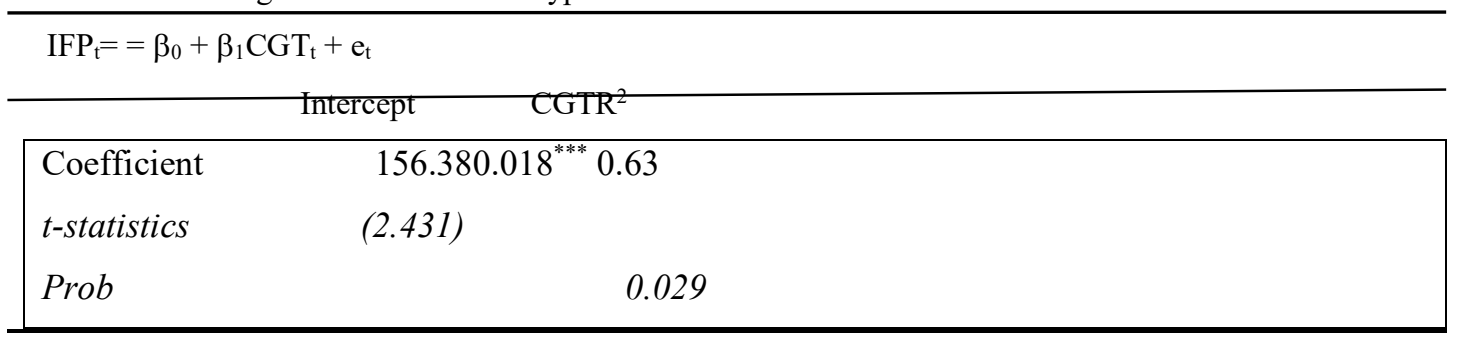

Panel C: OLS Regressions Result for Hypothesis 3

\begin{tabular}{lcc}
\hline $\mathrm{GDP}_{\mathrm{t}}==\beta_{0}+\beta_{1} \mathrm{CGT}_{\mathrm{t}}+\mathrm{e}_{\mathrm{t}}$ & \\
\hline \multicolumn{3}{l}{$\mathrm{CGTR}^{2}$} \\
\hline Coefficient & $4843.3715 .07^{* * *}$ & 0.87 \\
$t$-statistics & $(8.546)$ & \\
Prob & & 0.000 \\
\hline
\end{tabular}

Source: Researchers' E-View Regression Result

Table 5, Panel A indicates that the coefficient of capital gains tax (CGT) appears to be positive. This conforms to the apriori expectation. This means that a percentage increase in capital gains tax (CGT) will increase investment by 1.507 percent. Moreover, the value of the t-statistic for the slope coefficient is statistically significant. This is because the $\mathrm{t}$ - calculated of 7.296 has a p-value $=0.000$ which is less the alpha level of 0.05 . Thus, the study rejects the null hypothesis of $\mathrm{H} 1$ which states that "there is no significant relationship between capital gains tax and investment in Nigeria". The implication of this result is that CGT impact on investment is significantly high. Meaning that, CGT revenue coupled with other revenue from other sources can help Nigeria to make viable direct and portfolio investments.

In Panel B of table 5, the coefficient of capital gains tax (CGT) appears with a positive sign (0.018) implying a positive relationship between CGT and infrastructural facilities provision in Nigeria. This conforms to the apriori expectation. This means that a percentage increase in capital gains tax (CGT) will lead to 0.018 increases in the provision of infrastructural facilities. Stated differently, revenue from capital gains tax is used the provision of infrastructural facilities in Nigeria. The value of the t-statistic for the slope coefficient is significant. This is because the $\mathrm{t}$-calculated of 2.43 , has a $\mathrm{p}$-value $=0.029$ which is less than the 0.05 alpha level. Thus, the study rejects the second null hypothesis which states that "there is no significant relationship between capital gains tax (CIT) and infrastructural facilities provision in Nigeria".

At the same time, in Panel C of table 5, the coefficient of capital gains tax (CGT) appeared with a positive sign 
(15.07) which implies that a positive relationship between CGT and economic development exist. This conforms to the apriori expectation meaning that a percentage increase in capital gains tax will lead to 15.07 increases in economic development. In addition, the absolute value of the t-statistic for the slope coefficient is statistically significant. The t-statistics of 8.546 have a p-value of 0.000 , less than the 0.05 alpha levels. Thus, the study rejects the third null hypothesis which states that "there is no significant relationship between capital gains tax (CGT) and gross domestic products in Nigeria”.

The entire regression models are statistically fit with R-squared values of $0.75,0.63$ and 0.87 for model 1,2 and 3 respectively.

\subsection{Conclusion}

The study examines capital gains tax implications on investment, infrastructural facilities provision and gross domestic products in Nigeria. The theoretical literature upon which this work hinged on included, socio-political theory, expediency theory, faculty theory and benefit received theory. To achieve the objectives of the study, data were collected on capital gains tax (CGT) from the Federal Inland Revenue Service (FIRS), and data for gross domestic products (GDP), Direct and Portfolio Investment (INV) as well as infrastructural facilities provision (IFP) collected from Central Bank of Nigeria (CBN), Statistical bulletin, 2017. Descriptive statistics and correlation analysis were performed, the Augmented Dickey Fuller Unit Root test and Johenson Co-integration test of econometrics adopted to analyse the data and the formulated hypotheses tested using and Ordinary Least Square (OLS) .

The regression results revealed the following:

i. $\quad$ There is a significant relationship between capital gains tax (CIT) and investment in Nigeria

ii. There is a significant relationship between capital gains tax (CIT) and infrastructural facilities provision in Nigeria

iii. There is a significant relationship between capital gains tax (CGT) and gross domestic products in Nigeria

Capital gains tax has the ability to impact on the economy positively if properly and systematically integrated. The positive sign of the capital gains tax is an indicator that Nigeria at large is benefitting from CGT revenue; since revenue from tax are used by government to finance its major economic projects. The implication is that tax revenue has contributed much to the growth of Nigeria's economy, as one of the main purposes of tax revenue is to raise revenue that the government can use to provide adequate amenities and infrastructure, undertake viable investments as well as enhance growth and development.

This study recommended that the government and tax authorities should ensure that capital gains tax is properly administered through adequate sensitization of the citizenry, and efficiently managed and accounted for, so as to reap the advantages it confers on investments, infrastructural facilities provision and gross domestic products in Nigeria.

\section{References}

Abata, M. A. (2014). The impact of tax revenue on Nigerian economic (Case of Federal Board of Inland Revenue). Journal of Policy and Development Studies, 9 (1), 109- 121.

Adebayo, O. (2017). Capital gain tax as a veritable source of Revenue for the Government. Retrieved fromwww.academia.edu.../capital gains tax as...

Adefila, J. O., \& Bulus, J. S., (2014). Spatial inequalities in infrastructural development in Plateau state, Nigeria. American International Journal of Contemporary Research, 4(7), 89- 97.

Aguolu, O. (2014). Taxation and Tax management in Nigeria. Ezu Books Ltd. Enugu Nigeria

Azubuke, K. (2009). Marginal tax and its effects on the economy. Pals publishers, Onitsha.

Babalola, S. J. \& Aminu, U. (2011). "Fiscal Policy and Economic Growth Relationship in Nigeria", International Journal of Business and Social Sciences, 2 (17).

The Capital Gains Tax Act, CAP 354 LFN; 1990.

Central Bank of Nigeria (CBN) Statistical bulletin, 2017.

Chibu \& Njoku (2015). Annual Report 2015 - Corporate Activities of Standard Alliances Insurance Plc. Economic Review, 40: $1521-40$.

Edame, G. E. \& Okoi, W. W. (2014). The Impact of Taxation on Investment and Economic Development in Nigeria. Academic Journal of Interdisciplinary Studies MCSER Publishing, Rome-Italy. E-ISSN 2281-4612 ISSN 2281-3993. 3 (4)

Edame, E. (2011). The Essential of public finance and Public financial management in Nigeria. (3 ${ }^{\text {rd }}$ Revised Ed.) Calabar, Wusen Press Ltd

Edotsu, N. W. (2008). Taxation in Nigeria: Principles and Practice .Cavalet Publications

Embuka, A. (2014). Capital Gains Tax: An Untapped Revenue Goldrnine, Retrieved on 23rd November, 2016, from ww.peoplesdailyng.com/thee-an- 
Engen, E. M. \& Skinner, J. (1999). Taxation and economic growth, in Tax Policy in the Real World (Ed.) J. Slemrod, Cambridge University Press, New York, 305-30.

Ezemma, J. C. (2013). Administration and collection of value added tax (VAT) in Government Parastatals in Enugu and Anambra States, Nigeria.

Ezemma, J. C. \& Mohammed, K. (2017). The Challenges of Capital Gains Tax in Nigeria. International Journal of Communication. Published by Communication Studies Forum, Department of Mass Communication, University of Nigeria, Nsukka

Federal Inland Revenue Service, 2014. Annual summary of collected tax in Nigeria. Available from www.firs.gov.ng.

Ipaye, A. (2017). Capital gain tax. Chartered Institute of Taxation, Nigeria. Retrieved from www.academia. Edu./capital gain tax...

Kenyan Academia (2017). Capital Gains Tax in Kenya, the challenges. Retrieved from www.academica.edu/.../capital gains tax in Kenya.

Marotta, D. J. (2017). Ways to avoid paying capital gains. Available on www.forbes.com/sites/davidmarotta/fourteen-ways-to-avoid-paying-capital-gains

Musgrave, R. A. \& Musgrave, P. B. (2004). Public finance in theory and practice. $5^{\text {th }}$ Ed. New Delhi: Tata McGraw.

Mirrlees A. J. (1971). An Exploration in the Theory of Optimum Income Taxation. The Review of Economic Studies, 38 (2).

Nwite, C. S. (2015). The implications of tax revenue on the economic development Nigeria. Issues in business management and economics, 3(5), 74-80., 230- 238.

Okoi, W. W. \& Edame E, G. (2014). The Impact of Taxation on Investment and Economic Development in Nigeria

Okoli, M. N., \& Afolayan, S. M. (2015). Correlation between Value Added Tax (VAT) and national revenue in Nigeria: An ECM model. Research Journal of Finance and Accounting. 6(6)

Osho, A. E., Ajibola, I. O. \& Omolola, R. A. (2019). The Impact of Capital Gain Tax on Investment, Social and Economic Development in Nigeria. European Journal of Business and Management. 11 (2): 30-38.

Pigou Arthur Cecil (1920). The Economics of Welfare.

Ramsey F. P. (1927).A Contribution to the Theory of Taxation

Tosun, M. S \& Sohrab, A. (2005). Economic Growth and Tax Components: An Analysis of Tax Challenges in OECD (Organisation for Economic Co-operation and Development) 